Egyptian Journal of Rabbit Science, 27 (2): 463- 484(2017)

\title{
INFLUENCE OF USING NATURAL FEED ADDITIVES ON SOME REPRODUCTIVE AND PRODUCTIVE PERFORMANCE OF DOE RABBITS.
}

\author{
M.M. Basyony and A. A. Azoz \\ Animal Production Research Institute, Agricultural Research Center, Dokki, \\ Giza, Egypt. Mohamed000basyony@yahoo.com
}

The present study aimed to investigate the effects of different levels of dietary supplementation of rocket (Eruca Sativa) seeds, carrot (Daucus Carota L) seeds or bay laurel (Bay laurel Nobilis L)., leaves and their mixed between them on some reproductive and productive traits, antioxidant status of doe rabbits and their offspring's, during the pregnancy and lactation periods, under the same conditions. Forty eight New Zealand White (NZW) doe rabbits about 6-7 months old (2.890-3.070 kg) were randomly allotted to eight dietary groups (6 rabbits in each treatment group). The first group was fed a basal diet as control group,(T1); while the experimental second to eighth groups were fed the basal diet supplemented with $1.0 \%$ rocket seed (T2); $1.0 \%$ carrot seed (T3); $1.0 \%$ bay laurel leaf (T4); $0.5 \%$ rocket seed $+0.5 \%$ carrot seed (T5); $0.5 \%$ carrot seed $+0.5 \%$ bay laurel leaf (T6); $0.5 \%$ rocket seed $+0.50 \%$ bay laurel leaf (T7) and $0.33 \%$ rocket seed $+0.33 \%$ carrot seed $+0.33 \%$ bay laurel leaf (T8), respectively. The experimental period lasted for 16 weeks.

Live body weights of does before and after parturition days and at first day of lactation were significantly higher $(P=0.05,0.002$ and 0.01) in all treated rabbits as compared to control group respectively, while the response of does live body weights at weaning day was not significant.

All treated groups had significantly higher total feed intake during pregnancy and lactation when compared to the control group. During pregnancy constantly plasma, antioxidant capacity and endogenous antioxidant enzymes in terms of glutathione peroxidase $(G P x)$ and superoxide dismutase (SOD) were higher in treated groups compared to the control group, however the effect was significant in some treated groups. Hence, lipid peroxidation in terms of TBARs was significantly reduced in all treated groups 
compared to control. Metabolic and sex hormones (T3 and E2) were significantly leveled up in all treated groups, while the effect on progesterone (P4) hormone was significantly higher for some treatments.

During lactation period weekly and total milk yield were higher in treated groups. The improvement of milk yield was significant increased in T3, T4, T7 and T8 compared to the control group. During lactation period data on plasma antioxidant, constituents and hormones followed the same trends as in these concerning pregnancy periods, where treated groups surpassed the control group and favored the parameters evaluated.

Litter size and weight at weaning significantly $(P=0.01$ and 0.004) increased for all feed additives compared to control, respectively. The same trends were observed in litters weight gain fed diets supplemented with different feed additives. Means of pre-weaning survival rate (\%) from birth to weaning age in the treatments groups were better significantly than control group.

Conclusively, the findings of this study demonstrated that dietary supplementation of feed additives rocket seeds and carrot seeds or Bay leaves individually or in combinations improved reproductive or productive performance of does, antioxidant status hormone function during pregnancy and lactation period of doe rabbits. Moreover, offspring of rabbits the best results were obtained supplementing $0.33 \%$ rocket seed $+0.33 \%$ carrot seed $+0.33 \%$ bay laurel leaf/ diet of litter weight at weaning.

Keywords: Rocket seeds, carrot seeds, Bay laurel leaves, productive, reproductive, antioxidants, doe rabbits.

No doubt that the functional feeds are widely predicted to become one of the biggest dietary trends of the next 25 years. Plants (whole plants, leaves or seeds, mainly used as feedstuffs) and their extracts (considered as additives) are being increasingly used in animal nutrition as appetizers, digestive and physiological stimulants, colorants, and antioxidants, and for the prevention and treatment of certain pathological conditions. Always researchers look for natural feed additives away of using antibiotic to face the challenge of meeting the requests of increasingly informed and demanding consumers for products that provide similar effects of natural and controlled origin, the so-called pro-nutrients (Rosen, 1996).

Herbs, spices, and their extracts are classified by habitat, part used, beneficial value, and type of administration. Although the difference 


\section{INFLUENCE OF USING NATURAL FEED ADDITIVES ON RABBITS}

465

between herbs and spices is unclear, it has been suggested that herbs tend to be of leaf origin and spices of stem, bark, and seed origin (Collin, 2006). They cover a wide range of activities and some have been associated with improvements in animal performance and increased nutrient availability. Plants have developed arrange of low molecular weight secondary metabolites that help them to prevent physiological and environmental stress, and resist pathogens (Wenk, 2003). Most of these active secondary metabolites are isoprene derivatives, flavonoids and glucosinolates. Reports on the effects of this group of feed additives on rabbit growth performance (Omer et al., 2012), antioxidant, and antibacterial activity (Al-Turki, 2007), meat quality (Cardinali et al., 2012), blood biochemical parameters (Al- Jowari, 2012), reproductive performance (El-Nattat and El-Kady, 2007) and doe milk production (Eiben et al., 2004) are still fairly scarce, however in growing rabbits, particularly weaners, digestive disturbances are the main cause of the morbidity and mortality that create important economic losses for rabbit farmers (Licois, 2004 and Marlier et al., 2006). Weaning is the period in which the bunnies are separated from their mothers, milk is substituted with solid feed, and the bunnies immune system is still immature (Carabaño et al., 2006 and Gidenne et al., 2005).

There is a growing interest in using natural sources of plants with medicinal properties, rocket (Eruca sativa) in Egypt has been stead increased for the strong demand to volatile oils for pharmaceutical purpose. This plant was found to be incarnate the body condition to counteract the stress of illness (Eisenberg et al., 1993). The rocket seeds contain carotenoids, vitamin $\mathrm{C}$, flavonoids such as appiin and luteolin and glucosinolates the precursors of isothiocyanates and sulfaraphene (Talalay and Fahey, 2001), volatile oils like myristicin, apiole $\beta$-phellandrene (Bradley, 1992; Leung and Foster, 1996). Glucosinolates were found to have several biological activities including anticarcinogenic, antifungal and antibacterial plus their antioxidant action (Kim et al., 2004). They also, contain $\mathrm{Zn}, \mathrm{Cu}, \mathrm{Fe}, \mathrm{Mg}, \mathrm{Mn}$ and other elements (Abdo, 2003), which increase immune response of addition rocket seed, in rabbit feed diets significantly improved daily body gain and feed conversion and decrease daily feed intake (El-Nomeary et al., 2016).

Also, bay laurel (Bay laurel Nobilis L), which was presented as high level of nutritional support due to the content of free sugars, organic acids, PUFA and tocopherols together with antioxidant activity, such as scavenging activity, reducing power and lipid peroxidation inhibition (Dias et al. 2014). Plasma TBARs a level was statistically lower in the rabbits 
receiving bay leaves in their diets and enhanced plasma TAC (Casamassima et al., 2017).

Carrot plants (Daucus Carota L) have also a unique combination of three flavonoids: kaempferol, quercetin and luteolin (Ching and Mohamed, 2001 \& Horbowicz, et al., 2008). They are also rich in other phenols, including chlorogenic, caffeic and $\beta$-hydroxybenzoic acids along with numerous cinnamic acid derivates. Seeds of carrot caused to decrease of cholesterol and have anti-bacterial, anti-fungal, anti-inflammatory and wound healing benefit, (Da Silva Dias 2014). Muralidharam et al. (2008) observed that levels of serum aspartame transaminase, alanine transaminase and lactate dehydrogenase were significantly lower in carrot seed extract fed rats. Moreover, Singh et al. (2010) observed that rats fed with carrot seeds showed a significant rise in levels of antioxidant enzymes such as SOD, catalase, and glutathione peroxidase as compared with the control group of rats.

Therefore, this study aimed to compare more correctly the single and mixed effects on reproductive and productive performance of does rabbits and their offspring's, as well as, antioxidant activities, during the pregnancy and lactation periods of four commercially available natural feed additives as Rocket (Eruca Sativa) seeds and carrot (Daucus Carota L) seeds or Bay laurel Nobilis L. leaf and their mixed between them, under the same conditions.

\section{MATERIALS AND METHODS}

The experimental work of this study was carried out at El Nobaria Animal Production Research Station, Behara Governorate, Animal Production Research Institute, Egypt. It was started in April, 2017 and lasted for 16 weeks.

A total of forty eight New Zealand White (NZW) does at maturation age (6 - 7 month), weighing 2.890-3.070 kg were equally divided into 8 experimental treatments ( 6 does in each treatment group) to study the response lof doe rabbits and their litters to dietary supplementation with Rocket (Eruca Sativa) seeds and carrot (Daucus Carota L) seeds or Bay laurel (Nobilis L.) leaves in according to the following treatments order

Treatment 1: Basal diet as a control group (T1).

Treatment 2: Control $+1.0 \%$ rocket seeds (T2).

Treatment 3: Control $+1.0 \%$ carrot seeds (T3).

Treatment 4: Control $+1.0 \%$ bay laurel leaves (T4).

Treatment 5: Control $+0.5 \%$ rocket seeds $+0.5 \%$ carrot seeds (T5).

Treatment 6: Control $+0.5 \%$ carrot seeds $+0.5 \%$ bay laurel leaves (T6). 
467

\section{INFLUENCE OF USING NATURAL FEED ADDITIVES ON RABBITS}

Treatment 7: Control $+0.5 \%$ rocket seeds $+0.50 \%$ bay laurel leaves (T7).

Treatment 8: Control $+0.33 \%$ rocket seeds $+0.33 \%$ carrot seeds $+0.33 \%$ bay laurel leaves (T8).

All animals were kept under the same environmental and managerial conditions. Mating was carried out at random between does and bucks and each doe was transformed to the buck's cage to be mated and returned back to its cage after mating. Each doe was palpated 10 days thereafter to detect pregnancy. Those, which failed to conceive, were returned to mating-buck at the day of test. The experimental rabbits were allotted in a windowed house. Flat desk cages $(60 \times 55 \times 40 \mathrm{~cm})$ provided with galvanized nests for does, feeders and drinker nipples. All kindling kits were remained in the nests with their dams for suckling from birth up to weaning at 28 days of age.

The basal ration was formulated and pelleted to meet the nutrient requirements of rabbits according to NRC (1977). The ration was offered to rabbits ad libitum. The ingredients and chemical composition of the pelleted ration are shown in Table 1. The samples of pelleted ration was analyzed for crude protein $(\mathrm{CP})$, crude fiber $(\mathrm{CF})$, ether extract $(\mathrm{EE})$, nitrogen-free extract (NFE) and ash according to A.O.A.C. (2003).

Body weight and feed intake of each doe rabbits during pregnancy and lactation periods were recorded weekly. Milk yield was estimated day after day by the difference in doe weight before and after suckling that occurred once every test day. The decrease in mother weight was considered as the milk yield. Litter size, litter weight ( $\mathrm{g}$ ) at birth and weaning were recorded as mass product/doe; pre-weaning survival rate $(\%)$ recorded too.

Blood plasma samples were withdrawn from ear vein at two phases; 1) at 18 day of pregnancy and 2) at 18 day of lactation (peak of milk production). Blood samples were collected from the ear vein of all does and immediately placed on ice in heparinized tubes. Plasma was separated by centrifugation at $1500 \mathrm{rpm}$ for $10 \mathrm{~min}$. and stored at $-60^{\circ} \mathrm{C}$. Thiobarbituric acid-reactive substances (TBARs) were measured using the method of Tappel and Zalkin (1959). Blood plasma glutathione peroxidase (GPx) activity assayed using the method of Chiu et al., (1976). Superoxide dismutase (SOD) activity was assayed according to Misra and Fridovich (1972). Total antioxidant capacity (TAC) was determined according to Diamond Biodiagnostic, Egypt. Also, the following blood plasma hormones were analyzed; Concentrations of total Triiodotyronine (T3), Estradiol (E2), and Progesterone (P4) in blood plasma were determined by means of duplicate determinations using commercial kits for clinical use in humans (El Borg Laboratories, Alexandria, Egypt). 
Table1. Ingredients and chemical analysis of the experimental diets.

\begin{tabular}{|c|c|c|c|c|c|c|c|c|}
\hline \multirow[t]{2}{*}{ Ingredients } & \multicolumn{8}{|c|}{ Experimental groups } \\
\hline & T1 & $\mathbf{T 2}$ & T3 & T4 & T5 & T6 & T7 & T8 \\
\hline Berseem hay & 34.0 & 34.0 & 34.0 & 34.0 & 34.0 & 34.0 & 34.00 & 34.0 \\
\hline Barley & 15.0 & 15.0 & 15.0 & 15.0 & 15.0 & 15.0 & 15.00 & 15.0 \\
\hline Rocket seed & 0.00 & 1.00 & 0.00 & 0.00 & 0.50 & 0.00 & 0.50 & 0.33 \\
\hline Carrot seed & 0.00 & 0.00 & 1.00 & 0.00 & 0.50 & 0.50 & 0.00 & 0.33 \\
\hline Bay laurel leaf & 0.00 & 0.00 & 0.00 & 1.00 & 0.00 & 0.50 & 0.50 & 0.33 \\
\hline Corn yellow & 10.8 & 10.8 & 10.8 & 10.8 & 10.8 & 10.8 & 10.80 & 10.8 \\
\hline Wheat bran & 13.3 & 12.3 & 12.3 & 12.3 & 12.3 & 12.3 & 12.30 & 12.31 \\
\hline Soybean meal(CP44\%) & 21.5 & 21.5 & 21.5 & 21.5 & 21.5 & 21.5 & 21.50 & 21.5 \\
\hline Molasses & 3.00 & 3.00 & 3.00 & 3.00 & 3.00 & 3.00 & 3.00 & 3.00 \\
\hline Lime & 1.00 & 1.00 & 1.00 & 1.00 & 1.00 & 1.00 & 1.00 & 1.00 \\
\hline Di-Ca phosphate & 0.30 & 0.30 & 0.30 & 0.30 & 0.30 & 0.30 & 0.30 & 0.30 \\
\hline $\mathrm{NaCl}$ & 0.50 & 0.50 & 0.50 & 0.50 & 0.50 & 0.50 & 0.50 & 0.50 \\
\hline Vit-min premix* & 0.30 & 0.30 & 0.30 & 0.30 & 0.30 & 0.30 & 0.30 & 0.30 \\
\hline Lysine & 0.15 & 0.15 & 0.15 & 0.15 & 0.15 & 0.15 & 0.15 & 0.15 \\
\hline Methionine & 0.15 & 0.15 & 0.15 & 0.15 & 0.15 & 0.15 & 0.15 & 0.15 \\
\hline Total & 100 & 100 & 100 & 100 & 100 & 100 & 100 & 100 \\
\hline \multicolumn{9}{|c|}{ Chemical analysis (\%) } \\
\hline Dry matter & 91.07 & 90.23 & 91.0 & 90.27 & 90.35 & 90.22 & 90.04 & 90.1 \\
\hline Organic matter & 84.18 & 83.75 & 83.99 & 83.37 & 83.57 & 83.75 & 83.04 & 83.22 \\
\hline Crude protein & 17.88 & 17.85 & 17.86 & 17.86 & 17.85 & 17.85 & 17.85 & 17.84 \\
\hline Ether Extract & 2.85 & 2.86 & 2.87 & 2.86 & 2.86 & 2.86 & 2.87 & 2.86 \\
\hline Crude fiber & 13.4 & 13.37 & 13.38 & 13.41 & 13.39 & 13.35 & 13.31 & 13.35 \\
\hline Ash & 6.89 & 6.48 & 7.01 & 6.9 & 6.78 & 6.47 & 7.0 & 6.88 \\
\hline NFE & 50.05 & 49.67 & 49.88 & 49.24 & 49.47 & 49.69 & 49.01 & 49.17 \\
\hline $\mathrm{NDF}^{* *}$ & 37.88 & 37.79 & 37.82 & 37.91 & 37.85 & 37.74 & 37.62 & 37.74 \\
\hline DE kcal/kg*** & 2500.20 & 2504.36 & 2502.98 & 2498.81 & 2501.59 & 2507.14 & 2512.69 & 2507.14 \\
\hline
\end{tabular}

* Vit. and Min. mixture: Each kilogram of Vit. and Min. mixture contains: 2000.000 IU Vit. A, 150.000 IU Vita. D, 8.33 g Vit. E, 0.33 g Vit. K, 0.33 g Vit. B1, 1.0 g Vit. B2, 0.33g Vit. B6, $8.33 \mathrm{~g}$ Vit.B 5, $1.7 \mathrm{mg}$ Vit. B 1,2 $3.33 \mathrm{~g}$ Pantothenic acid, $33 \mathrm{mg}$ Biotin, 0.83g Folic acid, $200 \mathrm{~g}$ Choline chloride, $11.7 \mathrm{~g} \mathrm{Zn}, 12.5 \mathrm{~g} \mathrm{Fe}, 16.6 \mathrm{mg} \mathrm{Se}, 16.6 \mathrm{mg}$ $\mathrm{Co}, 66.7 \mathrm{~g} \mathrm{Mg}$ and $5 \mathrm{~g} \mathrm{Mn}$..

$* * \mathrm{NFE}=$ Crude protein- Crude fiber- Ether Extract.

***Digestible energy (DE) of the experimental diets was calculated according to the equation described by Cheeke et al., (1987) as follows: $\mathrm{DE}(\mathrm{K} / \mathrm{cal})=4.36-$ $0.0491 \times \mathrm{NDF} \%, \mathrm{NDF}=28.924+0.657 \times \mathrm{CF} \%$.

$\mathrm{T} 1=$ Treatment 1: Control., $\mathrm{T} 2=$ Treatment 2 : Control $+1.0 \%$ rocket seeds, $\mathrm{T} 3=$ Treatment 3 : Control $+1.0 \%$ carrot seeds, $\mathrm{T} 4=$ Treatment 4 : Control $+1.0 \%$ bay laurel leaves, T5=Treatment 5 : Control $+0.5 \%$ rocket seeds $+0.5 \%$ carrot seeds, T6=Treatment 6 : Control $+0.5 \%$ carrot seeds $+0.5 \%$ bay laurel leaves, $\mathrm{T} 7=$ Treatment 7: Control $+0.5 \%$ rocket seeds $+0.50 \%$ bay laurel leaves, $\mathrm{T} 8=$ Treatment 8 : Control $+0.33 \%$ rocket seeds $+0.33 \%$ carrot seeds $+0.33 \%$ bay laurel leaves. 


\section{Statistical Analysis:}

Data were analyzed by Completely Randomized Design according to Sendecor and Cochran (1982) using the General Linear Models of SAS (2001) as following statistical model:

$$
Y_{i j}=\mu+T_{i}+\varepsilon_{i j} .
$$

Where, $Y_{i j}$ is the value measured, $\mu$ is the overall mean effect, $T_{i}$ is the $i_{t h}$ diet effect and $\varepsilon_{\mathrm{ij}}$ is the random error associated with the $\mathrm{j}_{\mathrm{th}}$ rabbits assigned to the $\mathrm{i}_{\text {th }}$ diet. Significant differences of $\mathrm{P}<0.05$ between means were determined using Duncan's Multiple Range Test (Duncan, 1955).

\section{RESULTS AND DISCUSSION}

\section{Body weight of does}

Body weights of doe rabbits as affected by studied feed additives displayed in Table 2. Results show that average doe body weight during pregnancy and lactation were significantly (P-0.05 and 0.01) affected by studied feed additives, except for weaning day, respectively.

Table 2: Effect of dietary treatments on live body weight and feed intake of does during pregnancy and lactation periods

\begin{tabular}{|c|c|c|c|c|c|c|c|c|c|c|}
\hline \multirow[t]{2}{*}{ Items } & \multicolumn{8}{|c|}{ Experimental treatment groups } & \multirow[t]{2}{*}{ SEM } & \multirow{2}{*}{$\begin{array}{c}P \text { - } \\
\text { value }\end{array}$} \\
\hline & T1 & $\mathbf{T 2}$ & T3 & T4 & T5 & T6 & T7 & T8 & & \\
\hline \multicolumn{11}{|l|}{ Body weight: } \\
\hline Initial LBW & 2980 & 2965 & 2890 & 2990 & 3010 & 3070 & 2985 & 2910 & 108.47 & 0.469 \\
\hline Before parturition day & $3140^{b}$ & $3300^{\mathrm{a}}$ & $3295^{\mathrm{a}}$ & $3325^{\mathrm{a}}$ & $3310^{\mathrm{a}}$ & $3350^{\mathrm{a}}$ & $3320^{\mathrm{a}}$ & $3290^{\mathrm{a}}$ & 67.91 & 0.05 \\
\hline After parturition day & $2690^{\mathrm{c}}$ & $2900^{\mathrm{a}}$ & $2790^{b}$ & $2800^{b}$ & $2910^{a}$ & $2980^{\mathrm{a}}$ & $2875^{\mathrm{ab}}$ & $2870^{\mathrm{ab}}$ & 55.69 & 0.002 \\
\hline At first day of lactation & $2720^{b}$ & $2950^{\mathrm{a}}$ & $2950^{\mathrm{a}}$ & $2890^{\mathrm{a}}$ & $2980^{\mathrm{a}}$ & $3050^{\mathrm{a}}$ & $2900^{\mathrm{a}}$ & $2915^{\mathrm{a}}$ & 57.81 & 0.01 \\
\hline At weaning day & 2815 & 2970 & 2970 & 2980 & 2985 & 3070 & 2975 & 2890 & 86.47 & 0.664 \\
\hline \multicolumn{11}{|l|}{ Total feed intake } \\
\hline Durin & $3575^{\mathrm{c}}$ & $3810^{\mathrm{ab}}$ & $3680^{b}$ & $3770^{\mathrm{ab}}$ & $3815^{\mathrm{ab}}$ & $3820^{\mathrm{a}}$ & $3730^{b}$ & $3870^{\mathrm{a}}$ & 101.91 & 0.05 \\
\hline During Lactation & $4190^{c}$ & $4640^{\mathrm{a}}$ & $4500^{\mathrm{ab}}$ & $4210^{\mathrm{b}}$ & $4310^{b}$ & $4275^{\mathrm{b}}$ & $4715^{\mathrm{a}}$ & $4615^{\mathrm{a}}$ & 130.24 & 0.0001 \\
\hline
\end{tabular}

a- c, Means within a row not sharing similar superscripts are significantly different.

$\mathrm{T} 1=$ Treatment 1 : Control, $\mathrm{T} 2=$ Treatment 2 : Control $+1.0 \%$ rocket seeds, $\mathrm{T} 3=$ Treatment 3 : Control $+1.0 \%$ carrot seeds, $\mathrm{T} 4=$ Treatment 4 : Control $+1.0 \%$ bay laurel leaves, T5=Treatment 5: Control $+0.5 \%$ rocket seeds $+0.5 \%$ carrot seeds, T6=Treatment 6 : Control $+0.5 \%$ carrot seeds $+0.5 \%$ bay laurel leaves, T7 $7=$ Treatment 7 : Control $+0.5 \%$ rocket seeds $+0.50 \%$ bay laurel leaves, $\mathrm{T} 8=$ Treatment 8 : Control $+0.33 \%$ rocket seeds + $0.33 \%$ carrot seeds $+0.33 \%$ bay laurel leaves.

Improved body weight $(\mathrm{P}=0.05)$ before parturition day was detected due to the addition all supplemented feed additives as compared with control group. Body weight after parturition day followed a downward trend when compared with the initial body weight of all the experimental treatment. 
However, addition different feed additives in doe rabbit's diets significantly $(\mathrm{P} \leq 0.002)$ gave higher body weights than those higher than those fed the control diet. Ibrahim (2005) showed that growing rabbits that fed diets including $0.5 \%$ and $1 \%$ rocket seed or $1 \%$ bay laurel leaf growth performance significantly $(\mathrm{P}<0.05)$ increase in comparison with control group. These improvements may be attributed to the properties of this material that act not only as antibacterial, antiprotozoal and antifungal but also as antioxidant (Bradley, 1992; Leung and Foster, 1996 and Zeweil et al., 2008). The decrease in body weight after parturition may be due to that low circulating levels of leptin and glucose immediately after kindling are related to that body energy stores are depleted by pregnancy or that no energy is available for body tissue deposition due to the very low feed intake at kindling (Parigi Bini et al., 1990a; Houseknecht and Spurlock, 2003; Xiccato et al., 2005). Also, addition different levels of feed additives may be able to retrieve body condition, reduced physiological stress of lactation on the does, as well as, reducing the demand on the body reserves of does.

During lactation period, body weight of rabbits fed diets supplemented with different feed additives was significantly $(\mathrm{P} \leq 0.01)$ higher as compared with control group at $1^{\text {st }}$ day of lactation period. At weaning day body weight of doe's rabbits fed on diets including different levels of feed additives did not lose weight as compared with control group. In this respect and during lactation, the doe's body is subjected to a marked reduction in energy reserves following the mobilization of fat deposits (Pascual et al., 2000b, 2003). Unlike in treatment group addition additives help this energy loss remains constant throughout lactation (Parigi Bini et al., 1990b) and no recovery is observed during the final phase due to the milk energy output, which remains high even after 25-30 days of lactation. However, El-Tohamy and El-Kady (2007) found that the replacement of rocket meal to 50\% crude protein level of soybean meal showed significant augmentation in the performance of rabbits. Similar trend obtained by El-Nomeary et al., (2015) who found that growth performance was improved significantly when growing rabbits fed on diet supplemented with $3 \%$ rocket seeds meal for 68 days.

\section{Total feed intake of does}

Data on the effect of studied treatments on total feed intake is presented in Table 2. Total feed intake of doe's rabbit during pregnancy and lactation periods were significantly higher $(\mathrm{P} \leq 0.01$ and $\mathrm{P} \leq 0.05)$ in tested groups as compared to control. The highest feed consumption were by does supplied with $0.5 \%$ carrot seeds $+0.5 \%$ bay laurel leaves and $0.33 \%$ rocket seeds $+0.33 \%$ carrot seeds $+0.33 \%$ bay laurel leaves during pregnancy period. 
In this concern, Ibrahim (2005), who found that daily feed intake for growing rabbits, received either rocket or bay laurel leaf at the level of 0.5 and $1 \%$ increased significantly as compared to the control group, which may be due to its beneficial effect for stimulating and activating the digestive system by improving the diet palatability and enhancing appetite.

During lactation period rabbit doe supplied with $1.0 \%$ rocket seed. $(0.5 \%$ rocket seed $+0.50 \%$ bay laurel leaf $)$ and $(0.33 \%$ rocket seed $+0.33 \%$ carrot seed $+0.33 \%$ bay laurel leaf) in their diet caused to increase $(\mathrm{P}=$ 0.0001 ) in total feed intake of does in comparison with other treatments and does fed the control diet. In this term El-Nomeary et al., (2016) found that growth performance were improved significantly when rabbits were fed on diet supplemented with black cumin (Nigella sativa), mustard (Sinapis alba), sesame (Sesamum indicum) and rocket (Eruca sativa) seeds meals as feed additives for 68 days. Such improvement of tested materials may be attributed to the properties of those materials that could be considered as anti-bacteria, anti-protozoal, anti-fungal and anti-oxidants.

Thus, such assimilation didn't affect the palatability and voluntary feed intake in rabbits.

\section{3- Milk yields of does}

Milk production (g) of does during lactation periods were significantly affected by feed additives supplementation as compared to the control (Table 3). Does rabbit supplied with 1.0\% carrot seed. $1.0 \%$ bay laurel leaf, $(0.5 \%$ rocket seed $+0.50 \%$ bay laurel leaf $),(0.33 \%$ rocket seed $+0.33 \%$ carrot seed $+0.33 \%$ bay laurel leaf), in their diets constantly had a higher caused milk yield in comparison with other. Meanwhile, addition $1.0 \%$ rocket seed in doe feed caused to increase significantly $\left((\mathbf{P}=\mathbf{0 . 0 5})\right.$ milk yield during mid lactation at $3^{\text {rd }}$ week when compared with control group. Also, addition of $0.5 \%$ carrot seed $+0.5 \%$ bay laurel leaf in doe feed caused to increase significantly $((\mathbf{P}=\mathbf{0 . 0 5})$ milk yield, during mid lactation at $4^{\text {th }}$ week when compared to control group. This could be due to that these additive improved secretions of metabolic hormones are altered in lactating does to favor mobilization of body reserves to support milk production. This improvement returned to the feed additives (rocket and carrot seed or bay laurel leaf) have high nutrient of vitamin A, betacarotene (Rinzler 1990) and vitamin C (Barillari et al., (2005), AbdelKhalek et al., (2008) indicated that vitamin $\mathrm{C}$ and $\mathrm{E}$ or their combination had the highest values for milk production during all lactation periods. 


\section{4- Biomarkers of antioxidant of does}

Effects of different feed additives (rocket seed and carrot seed or bay laurel leaf) on blood plasma antioxidant constituents of total antioxidant activity TAC, (mmol/l), superoxide dismutase SOD $(\mathrm{u} / \mathrm{l})$, glutathione peroxidase GPx (u/l) and thiobarbituric acid reactive substances TBARs, $(\mu \mathrm{mol} / \mathrm{ml})$ at 18 day mid pregnancy and lactation periods of does rabbits are presented in Table 3.

Generally, during pregnancy all studied additives improved the TAC, SOD, GPx values as compared to the control; however, the response was not significant for all treatments. Hence, all additive managed to decrease significantly $(\mathrm{P}=0.05)$ the TBARs as compared the control. As during pregnancy values of TAC, SOD, GPx and TBARs during lactation following the same trend, where all feed additives enhanced the oxidation of blood plasma compared to the control. Pregnancy is a period in life when oxidative stress can be expected due to a high energy demand and increased oxygen requirement (Ganong, 2005).These results confirm that the antioxidant activity of phenolic compounds in feed additives (rocket seed and carrot seed or bay laurel leaf) is mainly due to their reduction-oxidation (redox) reactions and chemical structure (Hanafi et al., 2010; Da Silva Dias 2014 and Chahal et al., 2017)). An elevation of various indices of oxidative stress during the physiological course of pregnancy has been shown (Arikan et al., 2001; Djordjevic et al., 2004; Little and Gladen 1999). During pregnancy, oxidative stress has been associated with reproductive problems such as pre-eclampsia and abortion (Poston and Raijmakers 2004). Our results regarding antioxidant enzymes (SOD, TAC and GPx ) are in good agreement with those of Casamassima et al., (2017) who reported that plasma TBARs levels were statistically lower in the groups receiving bay laurel leaves while it enhanced TAC, retinol and alfa-tocopherol in rabbit. Moreover, Carocho and Ferreira, (2013) notice that the antioxidant activity exerted by bay laurel leaves could be attributed to the ability of phenol compounds which act as donors of hydrogen, metal chelators and radical scavenger of peroxides and superoxide's.

The importance of these antioxidant enzymes is due to their involvement in the clearance of superoxide and $\mathrm{H} 2 \mathrm{O} 2$ to maintain the structure and function of biological membranes (McCord 2000). SOD plays a role in an antioxidant defense system (Khan1999). Choi et al., (2010) reported that GPx was effective in converting the oxidized glutathione into reduced glutathione and in removing $\mathrm{H} 2 \mathrm{O} 2$ created by oxidative stress. 


\section{5- Blood hormones}

Plasma hormones as Triiodothyronine (T3), Estradiol (E2) and Progesterone (P4) at 18 day mid pregnancy and lactation periods as affected by studied different levels of feed additives (rocket seed and carrot seed or bay laurel leaf) are presented in Table 4.

Almost for all studied feed additives during pregnancy and lactation, and with exceptions, there were significant increases in blood plasma of studied hormones compared to the control group. The most noticeable increase was in individual supplementation groups compared to combination groups. The increase in the concentration of E2 in groups under feeding additives (rocket seed and carrot seed or bay laurel leaf) may be due to changes in follicular steroidogenesis and circulating steroid concentrations (Novak et al., 2003). Also, Mao et a., (1999) supported these results. They reported that nutrition may influence reproductive performance by number of mechanisms, including central effects on gonadotropin secretion. Pharmacological studies showed that carrot seeds exhibit anti-fertility properties in females (Bhatnagar, 1995 and Majundar et al., 1998). In most mammals the progesterone (P4) secreted during pregnancy inhibits oestrus and the pregnant female refuses to mate, but a pregnant doe may accept mating throughout the pregnancy period. In the otherside, from the third to the 15th day after mating the progesterone rate continues to increase, then remains stationary and finally drops rapidly before parturition, Lebas et al., (1997).

Progesterone hormone level in blood plasma of pregnant does increased with the progress of pregnancy period reaching the highest level at day-14 of pregnancy and decreased thereafter (Gad Allah et al., 2005). This trend was similar to that shown by Meshreky and Metry (2000) and Ubilla et al. (2000).

Milk synthesis depends on prolactin, a lactogenic hormone. During pregnancy prolactin is inhibited by the oestrogens and by progesterone, Lebas et al., (1997). Lower blood T3 concentration could reduce the rate of oxidation and the rate of continuous breakdown and formation of protein and fat in the most, if not all mammary tissue (Riis and Madsen, 1985). In this context Todini et al., (2007) explain that during gravidity in all mammalian species increased thyroid activity and blood hormone levels.

\section{6- Litter performances of does}

Performance and survival rate (\%) of litters as affected by studied feed additives are displayed in Table 4. Results show that litter size at birth was not significantly affected by studied feed additives. Improved litter weight 
Table 4: Effect of dietary treatments on performance of Litter at birth and weaning of does.

\begin{tabular}{|c|c|c|c|c|c|c|}
\hline \multirow[b]{2}{*}{$\begin{array}{l}\text { Treatment } \\
\text { groups }\end{array}$} & \multicolumn{2}{|c|}{ At birth } & \multicolumn{2}{|c|}{ At weaning } & \multirow{2}{*}{$\begin{array}{l}\text { Weight } \\
\text { gain } \\
\text { (g) }\end{array}$} & \multirow{2}{*}{$\begin{array}{c}\text { Pre- } \\
\text { weaning } \\
\text { survival } \\
\text { rate, }(\%)\end{array}$} \\
\hline & $\begin{array}{c}\text { Litter } \\
\text { size }\end{array}$ & $\begin{array}{c}\text { Litter } \\
\text { weight }(g)\end{array}$ & $\begin{array}{c}\text { Litter } \\
\text { size }\end{array}$ & $\begin{array}{c}\text { Litter } \\
\text { weight }(g)\end{array}$ & & \\
\hline T1 & 7.34 & $296.26^{b}$ & $5.33^{\mathrm{b}}$ & $2478.5^{\mathrm{c}}$ & $2182.2^{\mathrm{c}}$ & $72.6^{b}$ \\
\hline $\mathrm{T} 2$ & 6.90 & $324.40^{\mathrm{ab}}$ & $6.90^{\mathrm{a}}$ & $3381.0^{\mathrm{ab}}$ & $3056.6^{\mathrm{ab}}$ & $100^{\mathrm{a}}$ \\
\hline T3 & 7.11 & $312.84^{\mathrm{ab}}$ & $7.11^{\mathrm{a}}$ & $3341.7^{\mathrm{ab}}$ & $3028.9^{\mathrm{ab}}$ & $100^{\mathrm{a}}$ \\
\hline T4 & 7.35 & $352.80^{\mathrm{a}}$ & $7.00^{\mathrm{a}}$ & $3080.0^{b}$ & $2727.2^{\mathrm{b}}$ & $95.2^{\mathrm{a}}$ \\
\hline T5 & 6.88 & $295.84^{b}$ & $6.45^{\mathrm{a}}$ & $3192.8^{\mathrm{ab}}$ & $2896.9^{\mathrm{ab}}$ & $93.9^{\mathrm{ab}}$ \\
\hline T6 & 7.12 & $291.92^{\mathrm{b}}$ & $7.12^{\mathrm{a}}$ & $3275.2^{\mathrm{ab}}$ & $2983.3^{\mathrm{ab}}$ & $100^{\mathrm{a}}$ \\
\hline T7 & 6.68 & $287.24^{b}$ & $6.50^{\mathrm{a}}$ & $2879.5^{\mathrm{b}}$ & $2592.3^{\mathrm{b}}$ & $97.3^{\mathrm{a}}$ \\
\hline $\mathrm{T} 8$ & 7.20 & $352.80^{\mathrm{a}}$ & $7.20^{\mathrm{a}}$ & $3600.0^{\mathrm{a}}$ & $3247.2^{\mathrm{a}}$ & $100^{\mathrm{a}}$ \\
\hline SEM & 0.72 & 76.31 & 0.36 & 58.34 & 36.7 & 23.11 \\
\hline P-value & 0.756 & 0.005 & 0.01 & 0.004 & 0.0001 & 0.01 \\
\hline
\end{tabular}

a-c Means within columns with no common superscripts are differ significantly.

$\mathrm{T} 1=$ Treatment 1: Control, $\mathrm{T} 2=$ Treatment 2 : Control $+1.0 \%$ rocket seeds, T3=Treatment 3: Control $+1.0 \%$ carrot seeds, $\mathrm{T} 4=$ Treatment 4 : Control $+1.0 \%$ bay laurel leaves, $\mathrm{T} 5=$ Treatment 5 : Control $+0.5 \%$ rocket seeds $+0.5 \%$ carrot seeds, T6=Treatment 6 : Control $+0.5 \%$ carrot seeds $+0.5 \%$ bay laurel leaves, T7=Treatment 7: Control $+0.5 \%$ rocket seeds $+0.50 \%$ bay laurel leaves, T8=Treatment 8: Control +

$0.33 \%$ rocket seeds+ $\quad 0.33 \%$ carrot seeds $+0.33 \%$ bay laurel leaves.

$(\mathrm{P}=0.005)$ at birth was detected due to the additives tried, especially feeding diets with $1.0 \%$ bay laurel leaf (T4) and $0.33 \%$ rocket seed $+0.33 \%$ carrot seed $+0.33 \%$ bay laurel leaf (T8). The significant higher litter weight may be due to the link metabolic status and neuroendocrine improve of growth and reproduction that may be altering by endocrine function during periods of supplementation, feed additives and lactation (Barb et al., 2001). Litter size at weaning was significantly $(\mathrm{P}<0.01)$ higher in all experimental feed additives when compared with control group. Does supplied at levels $0.33 \%$ rocket seed $+0.33 \%$ carrot seed $+0.33 \%$ bay laurel leaf in their diet resulted in a significant increase in litter weight at weaning followed by the rest of experimental treatments as compared to the control group. The same trends were observed in weight gain of litters does fed diets supplemented with different feed additives. Thus, litter weight at this time would expect to be a useful index for lactational performance (Knight et al., 1986). Thus, the increase in their weight gain may be due to the increase in milk yield (Table 3).

In this connection, Lebas et al. (1986) found close correlation between rabbit weight at 21 days and milk production between day 0 and day $21(\mathrm{r}=$ 0.92). On the other hand, Afifi et al., (1973) and El-Kelawy (1993) postulated that the mean bunny weight at birth or at weaning decreased with the increase 
of litter size at birth. The apparent increase in litter weight may be due to the increase of growth rate of offspring during lactation. Means of pre- weaning survival rate $(\%)$ from birth to weaning age in the treatments groups were 72.6, 100, 100, 95.2, 93.9, 100, 97.3 and 100\%, respectively (Table 3). The differences between the treatments were significant. This result indicated that feed additives (rocket seed and carrot seed or bay laurel leaf) supplementation reduced mortality rate from birth to weaning age and this reduction may be due to the increase in the defense mechanism system in these treatments.

Conclusively, the findings of this study demonstrated that dietary supplementation of feed additives rocket seeds and carrot seeds or Bay leaves individually or in combinations improved productive performance, antioxidant status hormone function during pregnancy and lactation period of doe rabbits. Moreover, feed additives have a high antioxidant capacity or are good antioxidant properties, especially for stressed doe rabbits.

In the present study on rabbits the best results were obtained supplementing $0.33 \%$ rocket seed $+0.33 \%$ carrot seed $+0.33 \%$ bay laurel leaf/ diet of litter weight at weaning.

\section{REFERENCE}

Abdel-Khalek A.M., Selim N.A., El-Medany Sh.A., Nada S.A. (2008). Response of doe rabbits to dietary antioxidant vitamins $\mathrm{E}$ and $\mathrm{C}$ during pregnancy and lactation. $9^{\text {th }}$ World Rabbit Congress - June 10-13, 2008 - Verona - Italy, 529-524).

Abdo, M. and Zeinab, A. (2003): Using Egyptian Eruca-Sativa meal in broiler ration with or without microbial phytase. Egypt. J. Nutrition. Feeds, 6, 97-114.

Afifi, E. A.; El-Tawil, E. A.; Galal, E.S.E. and El-Khshin, S. S. (1973): Some aspects of production in three breeds of rabbit and their crosses. 1. Average individual weight per litter at birth. Annuals Agriculture Science Faculty of Agriculture Ain Shams University, Cairo Egypt, 18: 32-41.

Al-Jowari, S.A., (2012): Effect of spices mixture on blood glucose and lipids profile in experimentally-induced oxidative stress female rabbits. Iraqi J. Sci., 53, 279-284.

Al-Turki, A., (2007): Antibacterial effect of thyme, peppermint, sage, black pepper and garlic hydrosols against Bacillus subtitles and Salmonella enteritidis. J. Food Agric. Environ., 5: 92-94. 
A.O.A.C., (2003). Official Methods of Analysis. AOAC International. $2^{\text {nd }}$ Revision, $17^{\text {th }}$ Edn., Association of Analytical Communities, Gaithersburg, MD., USA.

Arikan S, Konukoglu D, Arkkan Ç, Akcay T, Davas I. (2001): Lipid peroxidation and antioxidant status in maternal and cord blood. Gynecol Obstet Invest., 51: 145-149.

Barillari, J., Canistro, D., Paolini, M., Ferroni, F., Pedulli, G.F., Iori R. and Valgimigli, L. (2005): Direct antioxidant activity of purified glucoerucin, the dietary secondary metabolite contained in rocket (Eruca sativa mill) seeds and sporuts. J. Agric. Food. Chem., 6: 2475-2482.

Bhatnagar, U. (1995): Poscoital Contraceptive Effects of an Alcoholic Extract of the Daucus carota Linn Seed in Rats. Clinical Drug Investigation, 9, 30-36.

Bradley P.R. (1992): British Herbal Compendium, Vol. 1, Pp: 395-399. Boumemouth: British Herbal Medicine Association.

Carabaño, R., Badiola, I., Licois, D., Gidenne, T., (2006): The digestive eco system and its control through nutritional or feeding strategies. In: Maertens, L., Coudert, P. (Eds.), Recent Advances in Rabbit Sciences. ILVO, Merebleke, Belgium, pp. 221-227.

Cardinali, R., DalBosco, A., Mugnai, C., Mattioli, S., Ruggeri, S., DalleZotte, A., Sartori, A., Cullere, M. Castellini, C., (2012): Effect of different dietary aromatic essences on meat quality of rabbit. In: Proceedings of the $10^{\text {th }}$ World Rabbit Congress. Sharm ElSheikh, Egypt, pp. 925-929.

Carocho, M. and Ferreira, I.C.F.R. (2013): A review on antioxidants, prooxidants and related controversy: Natural and synthetic compounds, screening and analysis methodologies and future perspectives. Food and Chemical Toxicology, 51, 15-25.

Casamassima, D.; Chiosi, F.; Vizzarri, F.; Palazzo, M. and Costagliola, C. (2017): The effect of bay laurel nobilis on the blood and lenses antioxidant Activity in rabbit under fat-enriched diet. Physiol. Res., 66: 325-333.

Chahal, K.K.; Mandeep Kaur; Urvashi Bhardwaj; Nancy Singla and Amandeep Kaur (2017): A review on chemistry and biological activities of Bay laurel nobilis L. essential oil. Journal of Pharmacognosy and Phytochemistry, 6(4): 1153-1161.

Ching, L.S. and Mohamed, S. (2001): Alpha-Tocopherol Content of 62 Edible Tropical Plants. Journal of Agriculturaland Food Chemistry, 49, 3101-3105. 
Chiu, D.T.Y., Stults, F.H. and Tappel, A.L. (1976): Purification and properties of rat lung soluble glutathione peroxidase. Biochimica et Biophysica Acta , 445: 558-566.

Choi C-S, Chung H-K, Choi M-K, Kang M-H. 2010. Effects of grape pomace on the antioxidant defense system in diet-induced hypercholesterolemic rabbits. Nutr. Res. Pract., 4:114-120.

Collin, H., (2006): Herbs, Spices And Cardiovascular Disease. In: Peter, K.V. (Ed.), Handbook of Herbs and Spices Vol. 3. Whood head Publishing Limited, Cambridge, England, pp. 126-137.

Da Silva Dias, J.C (2014): Nutritional and health benefits of carrots and their seed extracts. Food and Nutrition Sciences, pp: 2147-2156.

Dias M.I., Barros L., Dueñas M., Alves R.C., Oliveira M.B., SantosBuelga C. and Ferreira I.C. (2014): Nutritional and antioxidant contributions of Bay laurel nobilis L. leaves: would be more suitable a wild or a cultivated sample? Food Chem., 156: 339-346.

Djordjevic, A.; Spasic, S.; Jovanovic-Galovic, A.; Djordjevic, R. and Grubor-Lajsic, G. (2004): Oxidative stress in diabetic pregnancy: SOD, CAT and GSH-Px activity and lipid peroxidation products. $J$. Matern-Fetal Neonatal Med., 16: 367-372.

Duncan D.B. (1955): Multiple range and multiple F. Test. Biometrics, 11, $1-42$.

Eiben, C., Rashwan, A.A., Kustos, K., Gódor-Surmann, K.,Szendrő, Zs., (2004): Effect of anise and fenugreek supplementation on performance of rabbit does. In: Proceedings of the $8^{\text {th }}$ World Rabbit Congress Puebla, Mexico, pp. 805-810.

Eisenberg, D.M.R.; Kessler C.; Foster C.; Norlock F.E.; Calkins D.R. and Delbanco T.L. (1993): Un-conventional medicine in the United States. Preference, Cost and patterns of use. N. England J. Med., 328, 246-252.

El-Kelawy, H. M. (1993):Studies on reproductive and productive performance in rabbits. Ph.D. Thesis Agric.Fac., Zagazig Univ., Zagazig, Egypt.

El-Nattat, W.S. and El-Kady, R.I., (2007): Effect of different medicinal plant seeds residues on the nutritional and reproductive performance of adult male rabbits. Int. J. Agric. Biol., 9:479-485.

El-Nomeary, S. A. A.; El- Kady, R. I.; El-Shahat, A. A. and El-Nattat W.S. (2016): Prolonged effect of some plant seeds meals supplementation on the performance and serum parameters in male rabbits. International Journal of Chem. Tech. Research, Vol.9, No.12 pp 68-80. 
El-Nomeary, Y.A.A., El-Kady, R.I. and El-Shahat, A.A. (2015): Effect of some medicinal seed meals supplementation and their effects on the productive performance of male rabbits. Int. J. Chem. Tech. Res., 8(6): 401-411.

El-Tohamy, M.M. and El-Kady, R.I. (2007): Partial replacement of soybean meal with some medicinal plant seed meals and their effect on the performance of rabbits. Int. J. Agric. Biol., 9 (2): 215-219.

Gad Allah, S.A. Z; Abu Ward, M. A. and Samoa Z. Metrecs (2005): Reproductive performance, litter traits and milk production of baladi red, v-line rabbit breeds and their crosses under Egyptian environmental conditions. Egyptian Journal of Rabbit Science, 15 (1): $45-61$.

Ganong, W.F. (2005): Review of medical physiology. $22^{\text {nd }}$ ed. New York (NY): McGraw-Hill Companies. ISBN: 978-0-07-160568-7.

Gidenne, T., Jehl, N., Perez, J.M., Arveux, P., Bourdillon, A., Mousset, J.L., Duperray, J., Stephan, S. and Lamboley, B. (2005): Effect of cereal sources and processing in diets for the growing rabbits. II. Effects on performances and mortality by enteropathy. Anim. Res., $54,65-72$.

Hanafi; Eman M. Hegazy, Rowida M. and Riad , H.A. Amer. (2010): bio-protective effect of eruca sativa Seed oil against the hazardus Effect of aflatoxin b1 in male - rabbits. International Journal of Academic Research, Vol: 2. No: 2 pp: 67-74.

Horbowicz, M., Kosson, R., Grzesiuk, A. and Bski, H.D. (2008): Anthocyanins of Fruits and Vegetables-Their Occurrence Analysis and Role in Human Nutrition. Vegetable Crops Research Bulletin, 68, 5-22.

Houseknecht, K. L. and Spurlock, M. (2003): Leptin regulation of lipid homeostasis: dietary and metabolic implications. Nutrition Research Reviews, 16, 83-96.

Ibrahim, S.A.M., (2005): Effect of some medicinal plants as feed additives on growth and some metabolic changes in rabbits. Egypt J. Nutr. Feeds, 8: 207-19.

Khan M.A. (1999): Chemical composition and medicinal properties of Nigella sativa Linn. Inflammo pharmacol., 7:15-35.

Kim S.J., Jin S. and Ishii G. (2004): Isolation and structural elucidation of 4-(B-d-lucopyranosyldisulfanyl) butyl glucosinolate from leaves of rocket salad (Eruca sativa L.) and its antioxidative activity. Biosci. Biotechnol., 68, 2444-2450. 
Knight P., Beard A, and Wrathall J. (1989): Evidence that the bovine ovary secretes large amounts of monomeric inhibin alpha subunit and its isolation from bovine follicular fluid. J. Mol. Endocrinol., 2:189-200.

Lebas, F., Coudert, P.; Rouvier, R. and Rochambeau, H. (1986): The rabbit Husbandry, health and production. Food and Agriculture Organization for the United Nations, Rome.

Lebas, F.; Coudert, P.; de Rochambeau, H. and Thébault, R.G. (1997): Animal Production and Health Series. FAO, ISSN 1010-9021.

Leung A.Y. and Foster S. (1996): Drugs and Cosmetics, $2^{\text {nd }}$ Encyclopedia of common natural ingredients used in food. New York: John Wiley and Sons, Inc., USA.

Licois, D., (2004): Domestic rabbit enteropathies. In: Proceedingsofthe $8^{\text {th }}$ World Rabbit Congress. Puebla, Mexico, pp. 385-403.

Little, R.E., and Gladen, B.C. (1999): Levels of lipid peroxides in uncomplicated pregnancy: a review of the literature. Reprod Toxicol 13: $347-352$.

Majundar, U.K., Gupta, M. and Patro, V.J. (1998): Studies on AntiFertility of Methanolic Extract of Daucus carota Linn. Seeds. Indian Journal of Natural Products, 14, 33-37.

Mao, J.; Zak, L.J.; Cosgrove, J.R.; Shostak, S. and Foxcroft, G.R. (1999): Reproductive, metabolic and endocrine responses to feed restriction and GnRH treatment in primiparous lactating sow. Animal Reproduction Science, 77:725-735.

Marlier, D., Dewrée, R., Lassence, C., Licois, D., Mainil, J., Coudert, P., Meulemans, L., Ducatelle, R. and Vindevogel, H. (2006): Infectious agents associated with epizootic rabbit enteropathy: isolation and attempts to reproduce the syndrome. Vet. J. , 172,493-500.

McCord, J.M. (2000): The evolution of free radicals and oxidative stress. Am. J. Med., 108:652-659.

Meshreky, Samia Z. and Metry, G. H. (2000): Effect of vitamin E and/or selenium injection on: I. Reproductive performance of New Zealand White and Baladi Black doe rabbits under climate conditions of middle Egypt. In the Proceeding of $3^{\text {rd }}$ All Africa Conf. Animal Agric. and $11^{\text {th }}$ Conf. Egyptian Soc. Animal. Prod., Alexandria, Egypt, (6-9 November), 587-595.

Misra, H.P. and Fridovich, I. (1972): The role of superoxide anion in the autoxidation of epinephrine and a simple assay for superoxide dismutase. Journal of Biological Chemistry, 247: 3170-3175. 
Muralidharan, P., Balamurugan, G. and Kumar, P. (2008): Inotropic and Cardioprotective Effects of Daucus carota Linn. On Isoproterenol- Induced Myocardial Infarction. Bangladesh Journal of Pharmacology, 3, 74-79.

Novak, S.; Almeida, F.R.C.L.; Cosgrove, J.R.; Dixon, W.T. and Foxcroft, G.R. (2003): Effect of pre-and post mating nutritional manipulation on plasma progesterone, blastocyst development, and the oviduct environment during early pregnancy in gilts. Journal of Animal Science, 81: 772-7833.

NRC. (1977): National Research Council: Nutrient Requirements of Rabbits. ( $2^{\text {nd }}$ rew.ed.). National Academy of science, Washington, DC. USA.

Omer, H.A.A., Ibrahim, Sh.A.M., Abedo, A.A. and Ali, F.A.F., (2012): Growth performance of rabbits fed diets containing different levels of energy and mixture of some medicinal plants. J. Agric. Sci., 4: 201-212.

Parigi Bini, R., Xiccato, G. and Cinetto, M. (1990a): Energy and protein retention and partition in pregnant and non-pregnant rabbit does during the first pregnancy. Cuni-Science, 6: 19-29.

Parigi Bini, R., Xiccato, G. and Cinetto, M. (1990b): Repartition de l'energie alimentaire chez la lapine non gestante pendant la premiere lactation. In: Proceedings 5èmes Journées de la Recherche Cunicole en France, Paris, Vol. II. Communication 47. ITAVI, Paris, France, pp. 1-8.

Pascual, J.J., Cervera, C. and Fernandez-Carmona, J. (2000): The effect of dietary fat on the performance and body composition of rabbits in their second lactation. Animal Feed Science and Technology, 86:191-203.

Pascual, J.J., Cervera, C., Blas, E. and Fernandez-Carmona, J. (2003): A high-energy diet for reproductive rabbit does: effect of energy source. Nutrition Abstracts and Reviews, Series B: Livestock Feeds and Feeding, 73, 27R-39R.

Poston L, Raijmakers, M.T. (2004): Trophoblast oxidative stress, antioxidants and pregnancy outcome - a review. Placenta, 25: 72-78.

Riis, P. M. and Madsen, A. (1985): Thyroxin concentration and secretion rates in relation to pregnancy, lactation and energy balance in goats. J. Endocrinol., 107: 421-427.

Rinzler, C.A. (1990): The Complete Book of Herbs, Spices and Condiments. Facts on File, New York, Oxford.

Rosen, D. (1996): Feed additive nomenclature. World Poultry Science. Journal, 52: 53-57. 
SAS, (2001): SAS/STAT Software, Release 8.02. SAS Institute Inc. Cary, North Carolina. USA.

Singh, K., Dhongade, H., Sing, N. and Kashyap, P. (2010): Hypolipidemic Activity of Ethanolic Extract of Daucus carota Seeds in Normal Rats. International Journal of Biomedical and Advance Research, 1, 73-80.

Talalay P., and Fahey J.W. (2001): Phytochemicals from crucierous plants protect against cancer by modulating carcinogen metabolism. $J$. Nutrition., 131, 3027-3033.

Tappel, A.L. and Zalkin, H. (1959): Inhibition of lipid peroxidation in mitochondria by vitamin E. Archives of Biochemistry and Biophysics, 80: 333-336.

Todini, L., A. Malaffati, A. Valbonesi, M. Trabalza- Marinucci and A. Debenedetti, (2007): Plasma total T3 and T4 concentrations in goats at diferent physiological stages, as affected by the energy intake. Small Rum. Res., 68: 285-290.

Ubilla, E.; Rebollar, P. G.; Pazo, D.; Esquifino, A. and Avarilo, J. M. R. (2000): Influence of doe-litter separation on sexual receptivity, fertility, plasma progesterone and oesradiol concentrations in lactating rabbits. $7^{\text {th }}$ World Rabbit Congress; Valencia, Spain, Volume A, 61-79.

Wenk, C. (2003): Herbs and botanicals as feed additives in monogastric animals. Asian Australas. J.Anim.,16: 282-289.

Xiccato, G., Schiavon, S., Gallo, L., Bailoni, L. and Bittante, G. (2005): Nitrogen excretion in dairy cow, beef and veal cattle, pig, and rabbit farms in Northern Italy. Italian Journal of Animal Science, 4 (Suppl. 3), 103-111.

Zeweil H.S., Ahmed M.H., El-Adawy M.M. and Zaki B. (2008): Effect of substitution rocket seed meal as a source of protein for soybean meal in diets of New Zealand White rabbits. $9^{\text {th }}$ World Rabbit Congress - June 10-13, Verona - Italy,????- ????. 


\section{أثر استخدام الاضافات الغذائية الطبيعية في علائق امهات الارانبعلى الأبلى والتناسلى. الأداءالأنتاجى على الطي}

\section{محمد بسيونىمحمد محمود ، أبو بكر أحمد عزوز 2} قسم بحوث تغذية الدو اجن: معهد بحوث الزو بكر الانتاج الحيو انى ـ مركز البحوث الزر اعية - وزارة

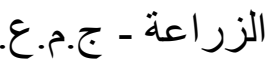
قسم بحوث تربية الار انب: معهد بحوث الانتاج الحيو انى- مركز البحوث الزراعيأح- وزارة

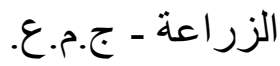

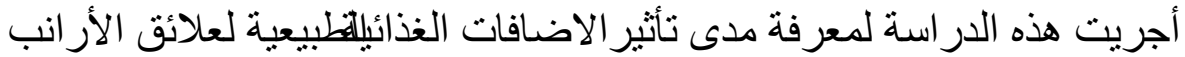

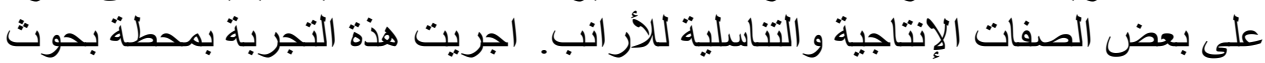

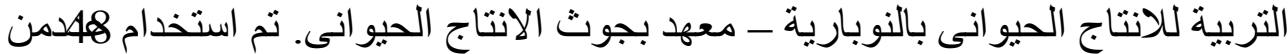

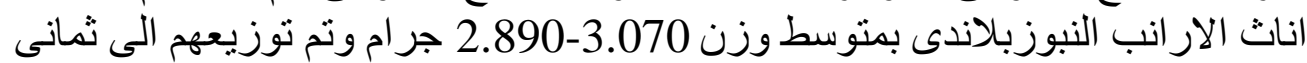

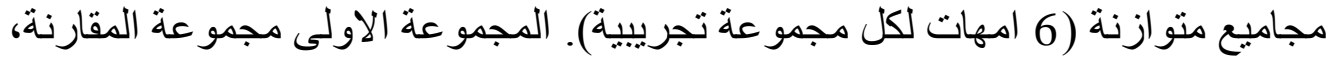

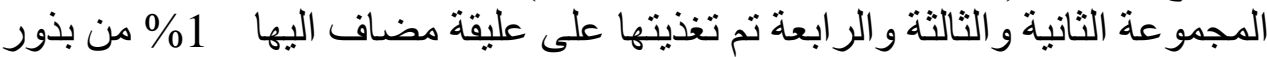

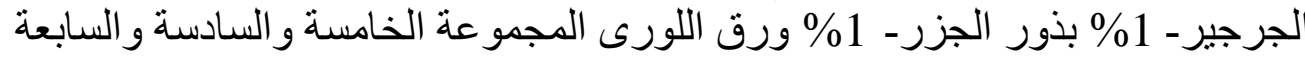

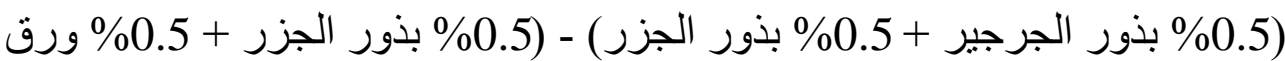

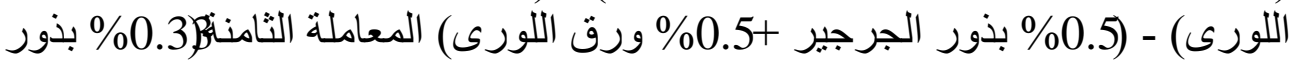

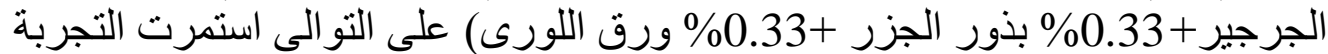

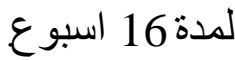

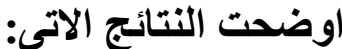

أن التغذية على علائق تحتوى على مستويات مختلفة من بذور الجرجير التورئ

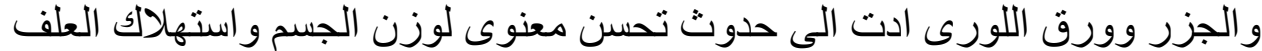

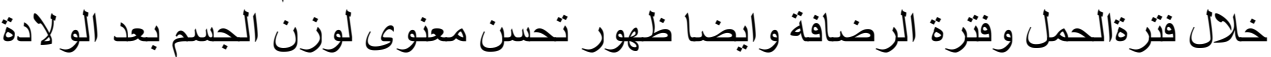

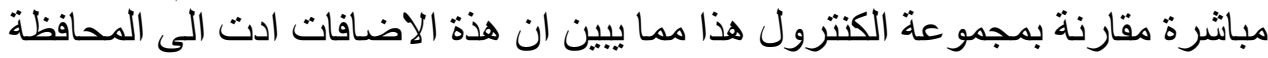

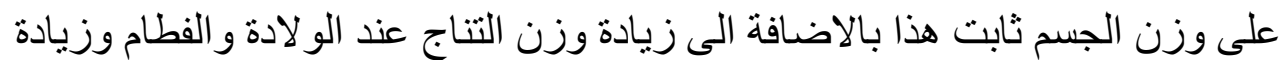

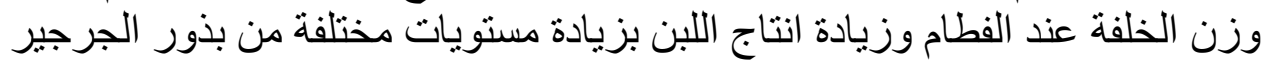

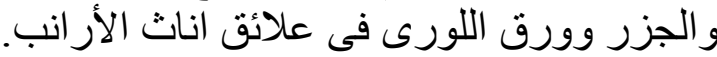

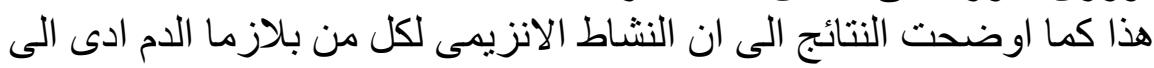

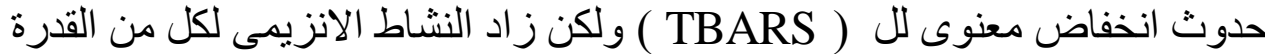

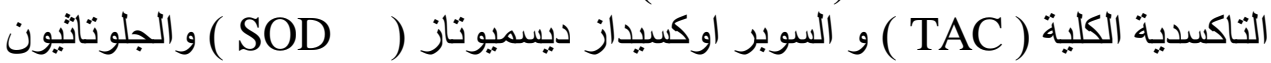

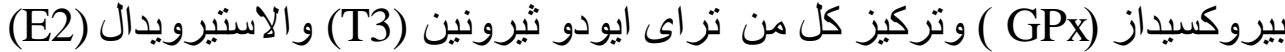

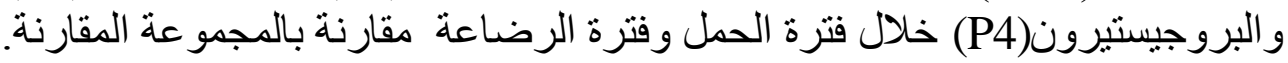


التوصية: هذه النتائج نوضح ان أستخدام الاضافات الغذائية الطبيعية ( بذور فئور

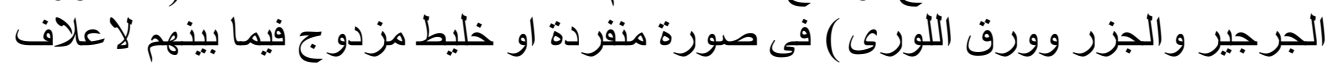

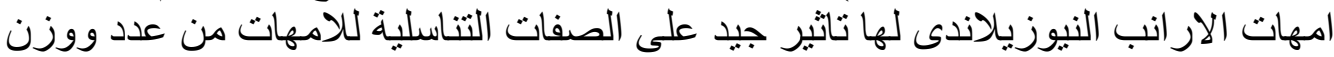

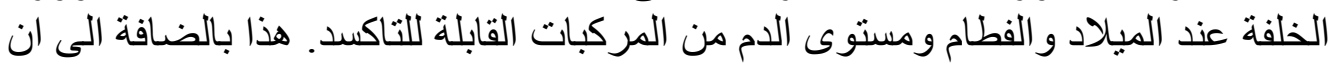

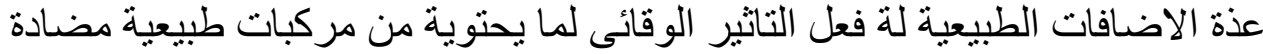

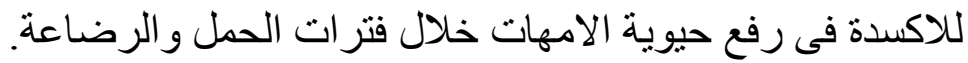

